Review

\title{
Improving Gander Reproductive Efficacy in the Context of Globally Sustainable Goose Production
}

\author{
Muhammad Faheem Akhtar ${ }^{1,2, *}$, Muhammad Shafiq ${ }^{3}$ (D) and Ilyas Ali ${ }^{4}$ \\ 1 Jiangsu Province Key Laboratory for Molecular and Medical Biotechnology, College of Life Science, \\ Nanjing Normal University, Nanjing 210023, China \\ 2 Research Institute of Donkey High-Efficiency Breeding and Ecological Feeding, College of Agronomy, \\ Liaocheng University, Liaocheng 252000, China \\ 3 Department of Cell Biology and Genetics, Shantou University Medical College, Shantou 515063, China; \\ drshafiqnjau@yahoo.com \\ 4 College of Animal Science and Technology, Nanjing Agricultural University, Nanjing 210095, China; \\ ilyasnjau@gmail.com \\ * Correspondence: 90741@njnu.edu.cn or faheem_dear@hotmail.com
}

check for updates

Citation: Akhtar, M.F.; Shafiq, M.; Ali, I. Improving Gander Reproductive Efficacy in the Context of Globally Sustainable Goose Production. Animals 2022, 12, 44. https://doi.org/10.3390/ ani12010044

Academic Editor: Jeffrey Downing

Received: 23 September 2021

Accepted: 19 December 2021

Published: 27 December 2021

Publisher's Note: MDPI stays neutral with regard to jurisdictional claims in published maps and institutional affiliations.

Copyright: (C) 2021 by the authors. Licensee MDPI, Basel, Switzerland. This article is an open access article distributed under the terms and conditions of the Creative Commons Attribution (CC BY) license (https:// creativecommons.org/licenses/by/ $4.0 /)$.
Simple Summary: High economic gains from commercial poultry breeder stocks cannot be achieved by ignoring the importance of highly efficient male breeders. Male stock provides the basis for progeny and also ensures optimum fertility and hatchability. The present review is written to explore the application of various techniques that can assist in improving the reproductive efficiency of goose ganders, which exhibit poor reproductive performance. Recommended techniques for improving gander reproduction are the use of an artificial photoperiod, nutritional supplementation, monochromatic light sources, artificial insemination and semen cryopreservation, as well as immunization against the leptin hormone, anti-Müllerian hormone, and glycoprotein inhibin.

\begin{abstract}
The goose is a popular poultry species, and in the past two decades the goose industry has become highly profitable across the globe. Ganders low reproductive performance remains a barrier to achieving high fertility and hatchability in subsequent flocks. To address the global demand for cheaper animal protein, various methodologies for improving avian (re)production should be explored. A large amount of literature is available on reproduction traits and techniques for commercial chicken breeder flocks, while research on improved reproduction in ganders has been carried out to a lesser extent. The present review aims to provide a comprehensive literature overview focusing on recent advancements/techniques used in improving gander reproductive efficacy in the context of ensuring a globally sustainable goose industry.
\end{abstract}

Keywords: goose; gander re(production); improved reproductive efficiency

\section{Introduction}

Sustainable goose production cannot be achieved without focusing on all production aspects, i.e., nutrition, management, biosecurity, and reproduction. Management and feeding can directly impact reproduction rate, fertility, hatchability, and the number of eggs and goslings produced [1]. In 2019, the estimated total number of commercial poultry birds in the world was 27.9 billion, including 3.62 million geese and guinea fowl [2].

In 2021, the human population increased to 7.9 billion [3] and is expected to grow to 9.3 billion in 2050 [4]. This situation requires exploration of ways to provide better quality, more hygienic, and cheaper protein sources from plants and animals. During the past three decades, the global waterfowl industry has been remodeled [5]. Figure 1 shows the commercial geese and guinea fowl stock statistics three decades ago, in 1990, in comparison with the 2019 data. According to FAOSTAT [2], the world leaders in geese production are China, Egypt, Hungary, Poland, the Russian Federation, and Madagascar. 


\section{World Goose and guinea fowl stock}
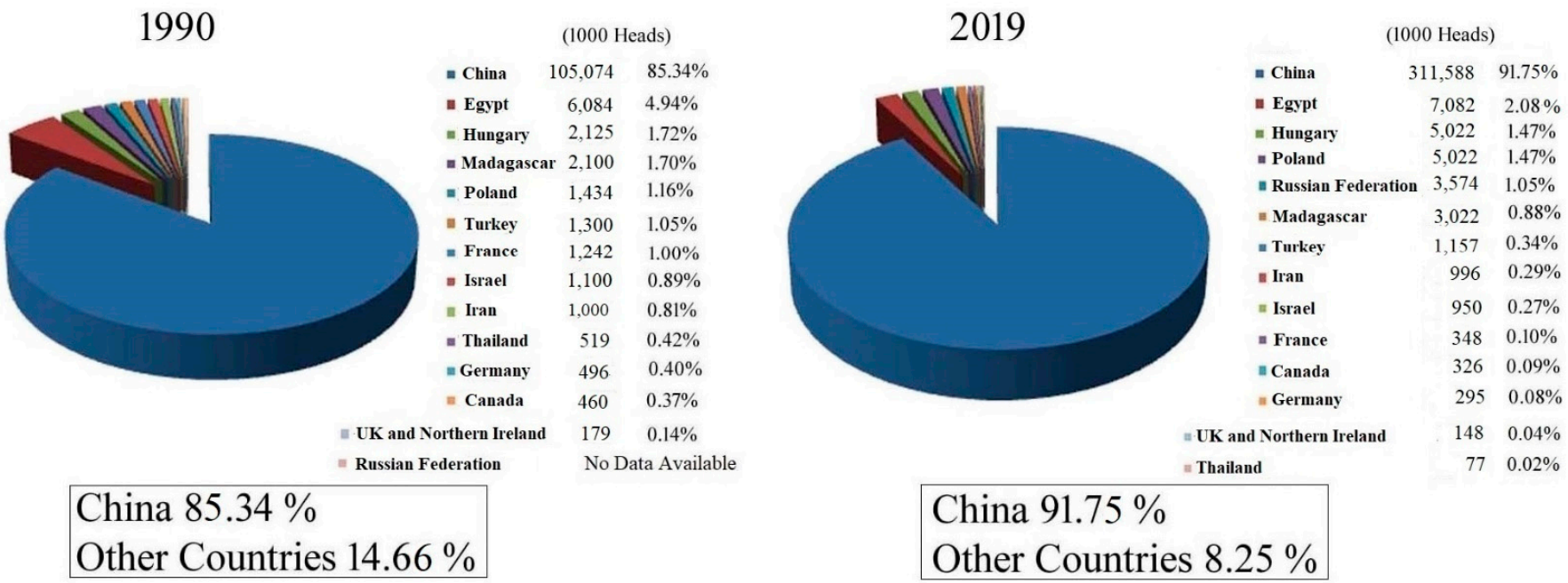

Figure 1. World goose and guinea fowl population in 1990 and 2019 according to FAOSTAT [2].

Geese are a popular source of eggs, meat, fat liver, goose fat, down, and feathers in numerous parts of the world [6-10]. Foie gras is a special food product obtained from duck and goose liver by gavage (force feeding) and is especially popular in French cuisine and countries such as Hungary, Poland, Israel, the USA, and Canada [9,10]. For more than 2000 years, goose feathers have been used for duvets and pillows [10]. Goose feathers and down originating from China, Hungary, Poland, and Canada are popular for filling mattresses, beddings, blankets, comforters, and furniture, having a lifespan of 50 years $[9,10]$. It is generally acknowledged that goose meat satisfies the human body's need for many nutrients [11]. However, compared to other commercial poultry species (broilers, layers, quail, and turkeys), low performance overall and, specifically, the poor reproductive efficiency of male breeder stock remain barriers to achieving a holistic production approach [12].

Ancestors of present goose breeds are wild geese; the majority of goose breeds in Europe belong to the graylag goose (Anser anser), and in Asia and Africa, they originated from the swan goose (A.cygnoides) [13,14]. Based on genetic, phenetic, phylogenetic, and historical analyses, it was hypothesized that there are six centers of goose domestication, breed formation, and dispersion: namely West-European, Chinese, Euro-Asiatic, Egyptian, North-American, and Australian [15]. As a result of domestication, the phenotypic traits of geese have been altered, and their production performance improved [16].

Health, hygiene, and good management of breeder stock is essential for best performance in the goose production business. Males should make up $50 \%$ of the flock to achieve the maximum number of fertile hatching eggs [17]. Good reproductive characteristics, i.e., hatchability and fertility, are extremely important when determining reproduction in ganders [5]. Fertility and hatchability are major components in improving the reproductive efficiency of breeder stock [16] and fertility in males. Nutrition, housing system, bird health, genetics, sexual behavior, female age, sex ratio, temperature, and light can affect fertility [16].

To sustainably optimize goose production, there is dire need to explore the various reasons for lower reproductive efficiency in ganders and recent solutions. The present review summarizes the current status of the world's goose industry in terms of reproduction and various aspects of poor reproductive efficiency along with recently developed methods to upgrade gander stock reproduction.

\section{Why Do Ganders Have Poor Reproductive Performance?}

The following are some reasons for the poor reproductive performance of ganders. 


\subsection{Seasonality}

Due to the strong seasonality of egg laying, the goose industry has remained underutilized for the past two decades. Goose breeds in China (the highest producer of geese globally, accounting for $95 \%$ of world goose production) are seasonal breeders, and may differ in breeding seasonality depending on their native habitat or locations [8]. Seasonal breeder birds exhibit three states of testes activity, i.e., matured testes, matured and active testes, and matured but resting testes [18].

The progeny of all goose breeds are either long day breeders or short day breeders depending on the latitude. Depending on seasonality, goose breeds are divided into three types [19]:

1. Long day breeders: inhabitants of the higher latitude $\left(40-45^{\circ} \mathrm{N}\right)$ temperate zone. They breed during the longer days in spring and early summer.

2. Inhabitants of the mid-latitude $\left(30-40^{\circ} \mathrm{N}\right)$ temperate regions. Their breeding season starts in autumn and ends in the following spring-early summer.

3. Short day breeders: inhabitants of subtropical areas $\left(22-25^{\circ} \mathrm{N}\right)$. Their breeding season starts from late summer to following spring.

In northern temperate zones, the majority of birds (including geese) have evolved altered endocrinological mechanisms (photoperiodism and photorefractoriness) that coincide with their breeding stage, characterized by periods of abundant food supply and supportive climatic conditions [18], particularly regarding photoperiod [19]. The purpose of this dynamic self-initiated alteration is to attain maximum reproductive efficiency. In short day breeder geese, spermatogenesis is depressed rather than considerably inhibited. In long day breeders, the testis and epididymis undergo marked structural changes to the extent that the testes lose shape and only Sertoli cells and spermatogonia remain in the seminiferous tubules.

Due to strong seasonality in breeding, ganders have lower testosterone $(\mathrm{T})$ concentrations and semen quality specifically in the nonbreeding seasons [20]. Ganders decline in fertility after two months of high reproductive efficiency with concomitant marked changes [21] in sexual behavior, endocrine parameters, and semen quality [21,22]. In peak breeding and nonbreeding seasons, marked changes and steroidogenic activity are observed in ganders [23]. Annual changes in the photoperiod alter the pituitary secretions of gonadotrophins during breeding seasons [19]. In birds, the anterior pituitary determines testes endocrinology through the luteinizing hormone (LH) and follicle stimulating hormone $(\mathrm{FSH})$ via hypothalamic gonadotrophin-releasing hormone $(\mathrm{GnRH})$ pulsatile secretion [24-26]. It is known that geese have a lower fertility and hatchability rate (53.8-84.72\% and 61-63\%, respectively) [16] compared to chickens (89-94\% and 90-92\%) [27] and ducks (75.9\% and 57.68\%, respectively) [28], which are further decreased during the breeding season.

\subsection{Poor Semen Quality}

Geese have the lowest reproductive efficiency of all poultry species, in addition to relatively poor semen quality and fertility [29]. One-year-old ganders have a large semen volume and a lower proportion of morphologically normal live spermatozoa compared to 2-year-old ganders [30]. Irrespective of age, the percentage of total live sperm was $91-95 \%$ but was $27-41 \%$ for morphologically normal sperm, with high percentages of defective sperm (bent neck, macrocephalic) [31]. Gumulka and Rozenboim [22], El-Hanoun et al. [32], and Kowalczyk and Lukaszewicz [33] observed lower sperm concentration and live spermatozoa count in the second half of the breeding season in ganders. The decrease in fertility in the second half of the breeding season may be associated with depressed semen quality and lower T concentrations [34]. From this work, it can be concluded that semen quality declines faster for ganders than cocks.

Prolactin (PRL) seems to mediate lower T and LH concentrations [26]. In Magang ganders, T concentration followed LH concentration, while the seasonal pattern of PRL was opposite to LH and T [29]. The transition from a long to a short photoperiod stimulated 
testicular development and semen production, while from short to long photoperiod decreased semen and testicular size and arrested spermatogenesis in ganders. The LH receptor is positively correlated with $\mathrm{T}$ concentrations [35]. Seasonally, a high concentration of PRL is a negative regulator of LH, T [22], and semen quality in domestic ganders [36]. In various goose breeds, sperm quality had been improved by using artificial insemination (AI) and natural breeding [37]. In ganders, such factors as feeding, semen collection method, growing system, semen collection frequency, and breed traits affect sperm quality [38].

\subsection{Age of Maturity}

The traits for male breeder stock to optimize commercial farming are body weight (BW), feed efficiency, muscle growth, livability, age of maturity, and fertility. Compared to other commercial poultry species such as broilers, layers, ducks, pigeons and turkeys, geese take a longer time to mature. It was noted that 1-year-old geese mature at the age of $279.7 \pm 1.8$ days [21]. The age of sexual maturity for Yangzhou ganders is 227 days [5].

Breeding companies are focused on selecting superior performance in all traits of economic importance [39]. The feed conversion ratio is the most important trait to determine how much daily weight is gained after consuming how much feed. Poultry feed is the major cost of poultry production, i.e., $70 \%$ of poultry production. Hence, from the economic aspect, normally farmers prefer chickens because their return on investment is quicker, but there is a higher likelihood of greater investment in countries with a high consumer demand for goose meat and eggs. Pullets mature at 21 weeks of age, and broilers reach $2-2.2 \mathrm{~kg}$ at 38-42 days of age [40], while the majority of small, medium, and large sized goose breeds in the world mature after 200 days of age.

Commercial breeder stocks in poultry (including geese) are meant to exhibit efficient growth, increased muscle yield, and improved genetic potential [41-44]. In comparison with other commercial poultry male breeder stocks, it takes longer to develop male progeny of high genetic potential and earlier maturity in ganders despite the greater efforts and use of a wider variety of techniques.

\section{Methods to Improve Reproductive Efficiency of Ganders}

The following are various methods adopted by researchers to improve the reproductive efficiency of ganders.

\subsection{Artificial Photoperiod and Monochromatic Light Sources}

As discussed previously, to maximize genetic potential, reproductive activity is synchronized with changing seasons for the majority of geese, i.e., when food is plentiful, and the conditions are most optimal for the growth of their goslings. In wild goose species, this synchronization is beneficial; however, in commercial goose farming it remains a barrier to maximizing economic gains. Sun et al. [45] successfully introduced artificial lighting programs, also called out of season geese laying, that improved geese reproductive performance and resulted in profits four to six times higher than using the natural photoperiod [35].

In avian species, the anterior pituitary secretes gonadotropins $\mathrm{LH}$ and FSH that control the testes, while Leydig cells steroidogenesis is initiated and maintained by LH [46,47]. LH secretion is positively correlated with T concentrations and negatively correlated with PRL secretions [35,36]. High levels of PRL regress reproductive activities in birds [48,49]. Hence, altering the photoperiod of ganders, i.e., to the short photoperiod for Magang ganders, caused waning of PRL secretion and activation of GnRH, leading to elevated LH [35] that stimulated T concentrations. $\mathrm{T}$ is further utilized by Sertoli cells for nourishment of germ cells such as spermatogonia and spermatocytes for smooth progression of spermatogenesis [5]. In ganders, altering the photoperiod can help optimize reproductive performance. Gumulka and Rozenboim [22] concluded that T concentration is a poor indicator of semen production in Zatorska ganders. 
Artificial illumination promotes poultry reproduction and growth [50,51]. Varying light wavelengths exerts different stimulatory effects on retina photoreceptors, which affects gonadal development and efficiency [52-54]. Monochromatic white, red, and blue light were applied to 3-year-old Roman ganders, and only white light enhanced semen quality, motility, viability, and percentage of normal spermatozoa [55]. Egg production and activation of the reproductive system was achieved after white and red light-emitting diode illumination with a long photoperiod of $11 \mathrm{~h}$ in Yangzhou geese [56].

Various light colors directly affect reproductive organ development, sexual maturity, muscular development, and behavior [57-59]. Green light accelerated embryo development and earlier hatching in chickens [60,61]. Green light stimulated lowered hatching time in four layer breeds during embryogenesis [62]. Reproductive performance of White King pigeons was improved by blue $(480 \mathrm{~nm})$, red $(660 \mathrm{~nm})$, and green $(540 \mathrm{~nm})$ light stimulation for three months [63].

Poultry production and behavior are directly affected by different wavelengths of light, though color illumination has been reported in many reports [64]. Broilers gained more BW under blue and green light compared to red light [65]. Improved fertility and chick production was observed in broiler breeders using green light [66]. Green light improved egg quality in laying hens [67]. Growth, T concentrations, and skeletal myofiber growth was observed in broilers using green and blue light illumination [51]. These results suggest that monochromatic light has a tendency to increase T, egg quality, fertility, semen quality, BW gain, and hatchability in commercial poultry birds.

\subsection{Nutritional Supplementation}

In 3-year-old White Koluda ganders, manual semen collection and semen quality were improved after dietary supplementation of commercial feed with selenium $(0.3 \mathrm{mg} / \mathrm{kg})$ and vitamin E (100 mg/kg) [68]. In breeder geese, dietary supplementation with micronutrients (essential amino acids, vitamins, and trace elements) dissolved in drinking water at a daily dose of $50 \mathrm{~g} / 500 \mathrm{~kg}$ weight, 10 days before the onset of the laying period, followed by a 10 day interval without supplementation and then supplementation for 10 days until the end of laying period, improved egg production and laying intensity, but seldom improved egg fertility and hatching rates of goslings [69]. In other commercial avian breeder stock, addition of feed additives improved reproduction as well as semen quality.

Lycopene supplementation at 300,600, and $900 \mathrm{mg} / \mathrm{kg}$ elevated semen biochemical traits and improved reproductive performance [70]. In another study, $5 \mathrm{~g} / \mathrm{L}$ lycopene in drinking water improved fertility, sperm volume, and viability in roosters [71]. Moreover, $0.05 \mathrm{mg} / \mathrm{mL}$ lycopene in drinking water reduced oxidative damage in semen during cryopreservation in addition to elevating sperm viability [72].

Supplementation with the oxidative compound L-carnitine (LC) at doses of 50 and $150 \mathrm{mg} / \mathrm{kg}$ of BW for 12 weeks showed significant elevated seminal antioxidant enzymes and may ultimately improve semen quality in aging cocks [73]. Dietary supplementation with $125 \mathrm{mg} / \mathrm{kg}$ LC increased sperm concentration in White Leghorn roosters [74] and viability in motility quail [75]. Administration of $150 \mathrm{mg} \mathrm{LC} / \mathrm{kg}$ in the diet elevated sperm concentration, semen volume, and lowered concentration of defective sperm in male ducks [76]. LC supplementation improved sperm membrane functioning and increased mitochondrial and testicular activity [77-79], with elevated T, spermatogenesis, and sperm functioning $[73,78]$.

Supplementation of vitamin E and selenium yeast resulted in improvements such as increased hatchability, post hatch growth during the first 7 days, fertility, and embryo weights in guinea fowl [80]. Manganese (Mn) supplementation of $10 \mathrm{mg} / \mathrm{kg}$ of feed significantly increased sperm mass and lowered the frequency of abnormal sperm in cocks, while in dual purpose cross bred hens, $\mathrm{Mn}$ in the control diet $(16 \mathrm{mg} / \mathrm{kg}$ from raw materials and $20 \mathrm{mg} /$ from organic or inorganic source) can profoundly improve reproductive efficiency, egg production, quality, and economic gains [81]. D-aspartic acid is present at adequate levels in the testes of mature ducks during reproductive seasonality 
and its addition beneficially increased T secretion in vitro [82], while in aged roosters, reproductive parameters (semen quality, sperm concentration, penetration, motility, and membrane integrity) were increased at $200 \mathrm{mg} / \mathrm{kg} \mathrm{BW}$ [83]. Adding guanidinoacetic acid (GAA) at $1200 \mathrm{mg} / \mathrm{kg}$ for four weeks upgraded quail fertility [84], while the same GAA dosage elevated fertility in roosters [85]. Similarly, dietary supplementation of ginger increased antioxidant capacity in chickens and laying hens [86,87]. In male broiler breeders, dietary supplementation of $50 \mathrm{mg}$ chrysin improved fertility and semen quality $[88,89]$.

\subsection{Inhibin Immunization}

Inhibin (INH) is a heterodimeric glycoprotein $(31-34 \mathrm{KDa})$ found as two isotopes i.e., INH A $(\alpha-\beta A)$ and INH B $(\alpha-\beta B)$, that share a common $\alpha$ subunit, differ in the $\beta$ subunit, and play important roles in the hypothalamus pituitary gonadal (HPG) axis [90-92]. INH is a negative feedback regulator of FSH [93]. INH is secreted by Sertoli cells in male testes and granulosa cells of ovarian follicles in females [94]. In males, FSH directly acts on Sertoli cells that nourish germ cells, ultimately negatively effecting reproductive efficiency.

INH immunization is an effective tool for improving reproductive performance in various commercial animals and bird species. In Yangzhou ganders, immunization against the INH $\alpha$-subunit improved testicular weight and Sertoli cell development but lowered T concentration [95]. Plasma T concentrations are not standard for semen quality in goose flock management [22]. In Japanese quail, INH immunization expedited puberty and elevated hen-day egg production [96]. In Partridge Shank hen, the INH vaccine enhanced the production of antibodies against INH, follicular development, and egg production. In hens from juvenile state to sexual maturity, INH immunization upgraded rate of ovulation and follicular development without increasing FSH [97]. Immunization against the INH $\alpha$ subunit promoted testicular development in developing cockerels [98] without effecting FSH. However, INH immunization did not significantly enhance egg production in turkey hens [99]. $\alpha$-INH immunization improved daily sperm production in rams [100].

\subsection{Leptin Immunization}

Leptin (LEP) is a peptide hormone secreted from white adipocytes that plays a vital role in reproduction, nutrition, and energy reserves [101-103]. LEP plays an important role in regulation of reproduction and fertility via the HPG axis $[104,105]$. To explore the function of LEP protein and to improve reproductive efficiency in animals, LEP immunization was practiced in Yangzhou ganders and resulted in lowered T, sperm counts, and testes weight [106].

Immunization against the LEP receptor downregulated egg production and follicular development and lowered fat deposition in growing chickens $[107,108]$. Higher body fat is directly proportional to lower sperm concentration, sperm motility, and T in males $[109,110]$. LEP plays an important role in fertility and pubertal development [111]. LEP immunization lowered sperm count and motility in adult rats [112]. LEP immunization at $3 \mathrm{mg} / \mathrm{kg}$ lowered sperm concentration and motility, and an increased dose resulted in damaged testes [113].

\subsection{Artificial Insemination and Semen Cryopreservation}

In AI, semen is transferred into a female's vagina. The purpose of AI is to produce fertilized eggs between inseminations [114]. AI is extensively used in turkeys [114]. AI improved percentage hatchability and fertility compared to natural mating in guinea fowl [115]. A greater number of fertilized eggs was obtained in broiler breeder hens after application of AI [116]. Fertility rates after AI were elevated up to $80 \%$ in quail, being equivalent to natural mating results [117]. AI in large parrots proved a milestone in a species conservation program [118]. AI in poultry species results in efficient use of best sires at pedigree farms, i.e., one male and ten to twelve females compared to the conventional mating ratio of one male and three to four females [38]. For high egg production in ostrich, AI can replace the male presence for breeding [119]. 
Semen cryopreservation is an important method for storing reproductive cells and ensuring the genetic diversity of birds [120,121]. The genetic potential of wild and domestic birds can be preserved by semen cryopreservation [29,120,122]. A satisfactory fertility level was obtained with frozen-thawed semen in various poultry species $[29,123,124]$. The semen collection procedure is an important factor for gander quality semen $[31,125,126]$. Semen cryopreservation significantly affected semen quality parameters in 1-year-old ganders compared to older ganders [29]. The semen cryopreservation method worked effectively for White Koluda, graylag [127], and Large White geese [128]. Frozen-thawed semen of Chinese ganders can improve the fertility of White Roman geese at the end of the production season [129].

Due to semen compositional variations among mammalian and avian species, semen conservation techniques can be complicated and require further advancements as conditions vary among avian species. In addition, keeping avian semen fertile in the female genital tract after $\mathrm{AI}$ is another challenge as compared to mammalian species [122]. AI and semen cryopreservation are proven techniques for farm animal breeding. Improving fertility and hatchability requires technical assistance for semen collection, storage, and further application in breeder stock. Improper AI results in poor results [130]. Thawed semen alone cannot achieve improved fertility, and hatchability of eggs can also be higher [16]. The introduction of experienced ganders is recommended as they produce higher quality semen and copulations $[31,38,131,132]$. Before the onset of the reproductive season, male breeders should be preselected to ensure a sufficient amount of semen for female insemination [133].

\subsection{Anti-Müllerian Hormone}

The anti-Müllerian hormone (AMH) plays a vital role in Müllerian duct regression in the male fetus [134]. Serum AMH is a marker of Sertoli cell development $[135,136]$. The Sertoli cell is the central regulator of testis development [137]. Sertoli cells of fetal mammalian species secrete AMH [138]. Upregulation of AMH gene mRNA expression indicates Sertoli cell development [95]. AMH causes regression of the uterus, upper vagina, and fallopian tubes in female mammals [139]. In the human ovary, AMH is initially expressed in the granulosa cells of primary follicles, peaks in antral and small antral stages of follicular development, and subsequently declines [140].

Compared to mammals, the literature on AMH expression in avian species is scarce [141-143]. In broody Zhedong White geese, active immunization against the AMH protein elevated development of small yellow and preovulatory follicles that resulted in increased clutch size [144]. However, AMH active immunization is not yet well reported in ganders and needs to be explored in terms of gonadal function.

\section{Conclusions}

Low reproductive performance is a known problem of ganders. To optimize performance, a holistic approach should be adopted for improving breeder geese stock performance, including consideration of animal husbandry practices, disease prevention, staff training, crossbreeding, nutritional modulation, and biosecurity. Crossbreeding is also a proven method for developing more commercially productive strains, e.g., Yangzhou geese. Poultry production requires more attention from geese researchers and practitioners on all aspects of production, including improvement of gander reproduction. The development of breeds and keeping geese parent stocks are also economically prohibitive for research purposes and requires improved collaboration between academia and industry.

Author Contributions: Conceptualization, M.F.A.; methodology, M.F.A.; resources, M.F.A.; data curation, M.F.A., M.S., I.A.; writing—original draft preparation, M.F.A.; writing-review and editing, M.F.A., M.S., I.A. All authors have read and agreed to the published version of the manuscript.

Funding: Taizhou Science and Technology Support Project (TN202017).

Institutional Review Board Statement: Not applicable. 
Informed Consent Statement: Not applicable.

Data Availability Statement: Data is contained in cited references.

Conflicts of Interest: The authors declare no conflict of interest.

\section{References}

1. Buckland, R.B.; Gérard, G. (Eds.) Goose Production; FAO Animal Production and Health Paper 154; Food and Agriculture Organization of the United Nations: Rome, Italy, 2002.

2. FAOSTAT. Data: Crops and Livestock Products; Statistics Division, Food and Agriculture Organization of the United Nations: Rome, Italy, 2021. Available online: https:/ / www.fao.org/faostat/en/\#data/QCL (accessed on 9 November 2021).

3. Worldometer. Current World Population. Worldometers.info. Available online: https://www.worldometers.info/worldpopulation/ (accessed on 9 November 2021).

4. Ramachandran, R. Current and future reproductive technologies for avian species. Adv. Exp. Med. Biol. 2014, 752, 23-31. [CrossRef] [PubMed]

5. Akhtar, M.F.; Ahmad, E.; Mustafa, S.; Chen, Z.; Shi, Z.; Shi, F. Spermiogenesis, stages of seminiferous epithelium and variations in seminiferous tubules during active states of spermatogenesis in Yangzhou goose ganders. Animals 2020, 10, 570. [CrossRef] [PubMed]

6. Romanov, M.N. Goose production efficiency as influenced by genotype, nutrition and production systems. World's Poult. Sci. J. 1999, 55, 281-294. [CrossRef]

7. Tereshchenko, A.V.; Mikityuk, D.N.; Ryabokon, Y.A.; Ivko, I.I.; Melnik, V.A.; Ryabinina, E.V.; Khvostik, V.P.; Gorbanev, A.P. Geese on the Farm and in the Courtyard, 2nd ed.; Tereshchenko, A.V., Ed.; UAAS, Poultry Research Institute: Borky, Ukraine, 2008.

8. Shi, Z.; Sun, A.; Shao, X.; Chen, Z.; Zhu, H. Boosting the Economic Returns of Goose Breeding and Developing the Industry by Controlled Photoperiod for Out-of-season Reproduction. In Animal Environment and Welfare, Proceedings of the International Symposium on Health Environment and Animal Welfare, Rongchang, Chongqing, China, 23-26 October 2015; Ni, J.-Q., Lim, T.-T., Wang, C., Eds.; China Agriculture Press: Beijing, China, 2015; pp. 357-364.

9. Romanov, M.N. Geese. In Encyclopedia of Animal Science, 2nd ed.; eBook; Baer, C.K., Ullrey, D.E., Pond, W.G., Eds.; Taylor \& Francis Inc.: London, UK; CRC Press Inc.: Boca Raton, FL, USA, 2018; Volume 1, pp. 487-489. [CrossRef]

10. Kozák, J. Goose production and goose products. World's Poult. Sci. J. 2021, 77, 403-414. [CrossRef]

11. Goluch-Koniuszy, Z.; Haraf, G. Geese for slaughter and wild geese as a source of selected mineral elements in a diet. J. Elem. 2018, 23, 1343-1360. [CrossRef]

12. Tóth-Baranyi, I. Baromfiipari Is Meretek; Müszaki Könyvkiadó: Budapest, Hungary, 1957; pp. 372-384.

13. Silversides, F.G.; Crawford, R.D.; Wang, H.C. The cytogenetics of domestic geese. J. Hered. 1988, 79, 6-8. [CrossRef]

14. Huang, J.; Pingel, H.; Guy, G.; Łukaszewicz, E.; Baéza, E.; Wang, S. A century of progress in waterfowl production, and a history of the WPSA Waterfowl Working Group. World's Poult. Sci. J. 2012, 68, 551-563. [CrossRef]

15. Romanov, M.N. Evolution of domestic geese. Centres of domestication and dispersion. In New Investigations on Palearctic Geese; Gudina, A.N., Ed.; Zaporizhya Branch of the Ukrainian Ornithological Society, Zaporizhya State University: Zaporizhya, Ukraine, 1995; pp. 120-126.

16. Salamon, A. Fertility and hatchability in goose eggs: A review. Int. J. Poult. Sci. 2020, 19, 51-65. [CrossRef]

17. Procter, T.; Smith, D. Managing Breeding Stock for Optimal Performance. 6 August 2013. Poultry World. Available online: https: / / www.poultryworld.net/Breeders/General/2013/8/Managing-breeding-stock-for-optimal-performance-1327700W/ (accessed on 9 November 2021).

18. Jamieson, B.G. (Ed.) Reproductive Biology and Phylogeny of Birds, Part A: Phylogeny, Morphology, Hormones and Fertilization; CRC Press: Boca Raton, FL, USA, 2011.

19. Shi, Z.D.; Tian, Y.B.; Wu, W.; Wang, Z.Y. Controlling reproductive seasonality in the geese: A review. World's Poult. Sci. J. 2008, 64, 343-355. [CrossRef]

20. Zhu, H.; Chen, Z.; Shao, X.; Yu, J.; Wei, C.; Dai, Z.; Shi, Z. Reproductive axis gene regulation during photostimulation and photorefractoriness in Yangzhou goose ganders. Front. Zool. 2017, 14, 11. [CrossRef]

21. Gumułka, M.; Rozenboim, I. Mating activity of domestic geese ganders (Anser anser f. domesticus) during breeding period in relation to age, testosterone and thyroid hormones. Anim. Reprod. Sci. 2013, 142, 183-190. [CrossRef]

22. Gumułka, M.; Rozenboim, I. Breeding period-associated changes in semen quality, concentrations of LH, PRL, gonadal steroid and thyroid hormones in domestic goose ganders (Anser anser f. domesticus). Anim. Reprod. Sci. 2015, 154, 166-175. [CrossRef] [PubMed]

23. Leska, A.; Kiezun, J.; Kaminska, B.; Dusza, L. Seasonal changes in the expression of the androgen receptor in the testes of the domestic goose (Anser anser f. domestica). Gen. Comp. Endocrinol. 2012, 179, 63-70. [CrossRef] [PubMed]

24. El Halawani, M.; Rozenboim, I. The ontogeny and control of incubation behavior in turkeys. Poult. Sci. 1993, 72, 906-911. [CrossRef]

25. Romanov, M.N. Genetics of broodiness in poultry-A review. Asian-Australas. J. Anim. Sci. 2001, 14, 1647-1654. [CrossRef]

26. Gumułka, M.; Rozenboim, I. Effect of breeding stage and photoperiod on gonadal and serotonergic axes in domestic ganders. Theriogenology 2015, 84, 1332-1341. [CrossRef] 
27. Islam, M.S.; Howlider, M.A.R.; Kabir, F.; Alam, J. Comparative assessment of fertility and hatchability of Barred Plymouth Rock, White Leghorn, Rhode Island Red and White Rock hen. Int. J. Poult. Sci. 2002, 1, 85-90. [CrossRef]

28. Salamon, A.; Kent, J.P. Manual egg turning is necessary for optimal hatching in geese. Int. J. Poult. Sci. 2016, 15, 57-61. [CrossRef]

29. Lukaszewicz, E.; Kruszynski, W.; Fujihara, N. Effect of age on quality of fresh and frozen-thawed semen in White Italian ganders. Asian J. Androl. 2003, 5, 89-93.

30. Boz, M.A.; Baş, H.; Sarica, M.; Erensoy, K. The effects of natural mating and artificial insemination on reproductive traits of 1-and 2-year-old domestic Turkish geese. Vet. Res. Commun. 2021, 45, 211-221. [CrossRef]

31. Lukaszewiczl, E.; Furuta, H.; Xi, Y.-M.; Fujihara, N. Comparative study on semen quality of one-and two-year-old ganders during the entire reproductive season. Asian J. Androl. 2000, 2, 139-142.

32. El-Hanoun, A.M.; Attia, Y.A.; Gad, H.A.M.; Abdella, M.M. Effect of different managerial systems on productive and reproductive traits, blood plasma hormones and serum biochemical constituents of geese. Animal 2012, 6, 1795-1802. [CrossRef]

33. Kowalczyk, A.; Łukaszewicz, E. The possibility of obtaining intergeneric hybrids via White Kołuda (Anser anser L.) goose insemination with fresh and frozen-thawed Canada goose (Branta canadensis L.) gander semen. Theriogenology 2012, 77, 507-513. [CrossRef]

34. Zeman, M.; Košutzký, J.; Miček, L'.; Lengyel, A. Changes in plasma testosterone, thyroxine and triiodothyronine in relation to sperm production and remex moult in domestic ganders. Reprod. Nutr. Dev. 1990, 30, 549-557. [CrossRef]

35. Shi, Z.D.; Huang, Y.M.; Liu, Z.; Liu, Y.; Li, X.W.; Proudman, J.A.; Yu, R.C. Seasonal and photoperiodic regulation of secretion of hormones associated with reproduction in Magang goose ganders. Domest. Anim. Endocrinol. 2007, 32, 190-200. [CrossRef]

36. Péczely, P.; El Halawani, M.; Hargitai, C.; Mézes, M.; Forgó, V.; Janosi, S. The photorefractoriness in domestic goose: Effect of gonads and thyroid on the development of postbreeding prolactinemia. Acta Biol. Hung. 1993, 44, $329-352$.

37. Liu, S.J.; Zheng, J.X.; Yang, N. Semen quality factor as an indicator of fertilizing ability for geese. Poult. Sci. 2008, 87, 155-159. [CrossRef]

38. Łukaszewicz, E. Artificial insemination in geese. World's Poult. Sci. J. 2010, 66, 647-658. [CrossRef]

39. Thiele, H.-H. Duck meat production: Breeding Pekin ducks for the world market. Int. Hatch. Pract. 2016, 30, 23-25.

40. Srinivas, G. Economic Traits of Broilers and Layers. 19 December 2015. SlideShare from Scribd. Available online: https: / / www.slideshare.net/gurramsrinivas39/economic-traits-of-broilers-and-layers (accessed on 9 November 2021).

41. Bondarenko, Y.V.; Ryabokon, N.G.; Romanov, M.N. Genetic Principles of the Synthesis of Dimorphically Coloured Geese. In Proceedings of the 12th International Symposium on Current Problems in Avian Genetics, Prühonice, Czech Republic, 1-3 September 1997; World's Poultry Science Association, Průhonice near Prague: Czech Branch, Czech Republic, 1997; pp. 126-128.

42. Dunn, I.C.; Miao, Y.-W.; Morris, A.; Romanov, M.N.; Wilson, P.W.; Waddington, D.; Sharp, P.J. Candidate genes and reproductive traits in a commercial broiler breeder population, an association study. J. Anim. Sci. 2001, 79 (Suppl. S1), 43.

43. Gadyuchko, O.T.; Sakhatsky, N.I.; Tereshchenko, A.V.; Anisimov, V.I.; Kislaya, E.D.; Svinarev, V.F. Genetic potential of breeds and populations of geese in Ukraine. Ptakhivnistvo 2003, 53, 54-62.

44. Ruban, S.Y.; Prijma, S.V.; Fedota, O.M.; Lysenko, N.G. Animal genetic resources of Ukraine: Current status and perspectives. J. Vet. Med. Biotechnol. Biosaf. 2015, 1, 23-31.

45. Sun, A.D.; Shi, Z.D.; Huang, Y.M.; Liang, S.D. Development of out-of-season laying in geese and its impact on the goose industry in Guangdong Province, China. World's Poult. Sci. J. 2007, 63, 481-490. [CrossRef]

46. Thurston, R.J.; Korn, N. Spermiogenesis in commercial poultry species: Anatomy and control. Poult. Sci. 2000, 79, 1650-1668. [CrossRef]

47. Ubuka, T.; Son, Y.L.; Tobari, Y.; Narihiro, M.; Bentley, G.E.; Kriegsfeld, L.J.; Tsutsui, K. Central and direct regulation of testicular activity by gonadotropin-inhibitory hormone and its receptor. Front. Endocrinol. 2014, 5, 8. [CrossRef]

48. Goldsmith, A.R.; Nicholls, T.J.; Plowman, G. Thyroxine treatment facilitates prolactin secretion and induces a state of photorefractoriness in thyroidectomized starlings. J. Endocrinol. 1985, 104, 99-103. [CrossRef]

49. Dawson, A.; Sharp, P.J. The role of prolactin in the development of reproductive photorefractoriness and postnuptial molt in the European starling (Sturnus vulgaris). Endocrinology 1998, 139, 485-490. [CrossRef]

50. Olanrewaju, H.A.; Thaxton, J.P.; Dozier, W.A., III; Purswell, J.; Roush, W.B.; Branton, S.L. A review of lighting programs for broiler production. Int. J. Poult. Sci. 2006, 5, 301-308. [CrossRef]

51. Cao, J.; Liu, W.; Wang, Z.; Xie, D.; Jia, L.; Chen, Y. Green and blue monochromatic lights promote growth and development of broilers via stimulating testosterone secretion and myofiber growth. J. Appl. Poult. Res. 2008, 17, 211-218. [CrossRef]

52. Woodard, A.E.; Moore, J.A.; Wilson, W.O. Effect of wave length of light on growth and reproduction in Japanese quail (Coturnix coturnix japonica). Poult. Sci. 1969, 48, 118-123. [CrossRef]

53. Pyrzak, R.; Siopes, T.D. The effect of light color on egg quality of turkey hens in cages. Poult. Sci. 1986, 65, 1262-1267. [CrossRef]

54. Lewis, P.D.; Morris, T.R. Poultry and coloured light. World's Poult. Sci. J. 2000, 56, 189-207. [CrossRef]

55. Chang, S.-C.; Zhuang, Z.-X.; Lin, M.-J.; Cheng, C.-Y.; Lin, T.-Y.; Jea, Y.-S.; Huang, S.-Y. Effects of monochromatic light sources on sex hormone levels in serum and on semen quality of ganders. Anim. Reprod. Sci. 2016, 167, 96-102. [CrossRef]

56. Zhu, H.X.; Hu, M.D.; Guo, B.B.; Qu, X.L.; Lei, M.M.; Chen, R.; Chen, Z.; Shi, Z.D. Effect and molecular regulatory mechanism of monochromatic light colors on the egg-laying performance of Yangzhou geese. Anim. Reprod. Sci. 2019, 204, 131-139. [CrossRef]

57. Baxter, M.; Joseph, N.; Osborne, V.R.; Bédécarrats, G.Y. Red light is necessary to activate the reproductive axis in chickens independently of the retina of the eye. Poult. Sci. 2014, 93, 1289-1297. [CrossRef] 
58. Rozenboim, I.; Biran, I.; Chaiseha, Y.; Yahav, S.; Rosenstrauch, A.; Sklan, D.; Halevy, O. The effect of a green and blue monochromatic light combination on broiler growth and development. Poult. Sci. 2004, 83, 842-845. [CrossRef]

59. Parvin, R.; Mushtaq, M.M.H.; Kim, M.J.; Choi, H.C. Light emitting diode (LED) as a source of monochromatic light: A novel lighting approach for behaviour, physiology and welfare of poultry. World's Poult. Sci. J. 2014, 70, 543-556. [CrossRef]

60. Hassan, M.R.; Sultana, S.; Choe, H.S.; Ryu, K.S. Effect of monochromatic and combined light colour on performance, blood parameters, ovarian morphology and reproductive hormones in laying hens. Ital. J. Anim. Sci. 2013, 12, e56. [CrossRef]

61. Tong, Q.; McGonnell, I.M.; Demmers, T.G.M.; Roulston, N.; Bergoug, H.; Romanini, C.E.; Verhelst, R.; Guinebretière, M.; Eterradossi, N.; Berckmans, D.; et al. Effect of a photoperiodic green light programme during incubation on embryo development and hatch process. Animal 2018, 12, 765-773. [CrossRef]

62. Wang, P.; Sun, Y.; Fan, J.; Zong, Y.; Li, Y.; Shi, L.; Isa, A.M.; Wang, Y.; Ni, A.; Ge, P.; et al. Effects of monochromatic green light stimulation during embryogenesis on hatching and posthatch performance of four strains of layer breeder. Poult. Sci. 2020, 99, 5501-5508. [CrossRef]

63. Wang, Y.; Ding, J.T.; Yang, H.M.; Cao, W.; Li, Y.B. The effect of new monochromatic light regimes on egg production and expression of the circadian gene BMAL1 in pigeons. Poult. Sci. 2015, 94, 836-840. [CrossRef]

64. Liu, L.; Li, D.; Gilbert, E.R.; Xiao, Q.; Zhao, X.; Wang, Y.; Yin, H.; Zhu, Q. Effect of monochromatic light on expression of estrogen receptor (ER) and progesterone receptor (PR) in ovarian follicles of chicken. PLoS ONE 2015, 10, e0144102. [CrossRef]

65. Wabeck, C.J.; Skoglund, W.C. Influence of radiatn energy from fluorescent light sources on growth, mortality, and feed conversion of broliers. Poult. Sci. 1974, 53, 2055-2059. [CrossRef] [PubMed]

66. Cave, N.A. Effects of feeding level during pullet-layer transition and of pretransition lighting on performance of broiler breeders Poult. Sci. 1990, 69, 1141-1146. [CrossRef]

67. Er, D.; Wang, Z.; Cao, J.; Chen, Y. Effect of monochromatic light on the egg quality of laying hens. J. Appl. Poult. Res. 2007, 16, 605-612. [CrossRef]

68. Jerysz, A.; Lukaszewicz, E. Effect of dietary selenium and vitamin E on ganders' response to semen collection and ejaculate characteristics. Biol. Trace Elem. Res. 2013, 153, 196-204. [CrossRef] [PubMed]

69. Janan, J.; Tóth, P.; Hutás, I.; Treuer, Á.; Pali, J.; Csépányi, B. Effects of dietary micronutrient supplementation on the reproductive traits of laying geese. Acta Fytotech. Zootech. 2015, 18, 6-9. [CrossRef]

70. Al-Daraji, H.J.; Al-Jnabi, Y.A. Effect of dietary supplementation with lycopene on some semen biochemical traits of local ganders. Iraqi J. Biotechnol. 2015, 14, 282-295.

71. Mangiagalli, M.G.; Martino, P.A.; Smajlovic, T.; Guidobono Cavalchini, L.; Marelli, S.P. Effect of lycopene on semen quality, fertility and native immunity of broiler breeder. Br. Poult. Sci. 2010, 51, 152-157. [CrossRef]

72. Rosato, M.P.; Centoducati, G.; Santacroce, M.P.; Iaffaldano, N. Effects of lycopene on in vitro quality and lipid peroxidation in refrigerated and cryopreserved turkey spermatozoa. Br. Poult. Sci. 2012, 53, 545-552. [CrossRef]

73. Elokil, A.A.; Bhuiyan, A.A.; Liu, H.Z.; Hussein, M.N.; Ahmed, H.I.; Azmal, S.A.; Yang, L.; Li, S. The capability of L-carnitinemediated antioxidant on cock during aging: Evidence for the improved semen quality and enhanced testicular expressions of GnRH1, GnRHR, and melatonin receptors MT 1/2. Poult. Sci. 2019, 98, 4172-4181. [CrossRef] [PubMed]

74. Zhai, W.; Neuman, S.L.; Latour, M.A.; Hester, P.Y. The effect of dietary L-carnitine on semen traits of White Leghorns. Poult. Sci. 2007, 86, 2228-2235. [CrossRef] [PubMed]

75. Ahangari, Y.J.; Parizadian, B.; Akhlaghi, A.; Sardarzadeh, A. Effect of dietary l-carnitine supplementation on semen characteristics of male Japanese quail. Comp. Clin. Path. 2014, 23, 47-51. [CrossRef]

76. Al-Daraji, H.J.; Tahir, A.O. Effect of L-carnitine supplementation on drake semen quality. S. Afr. J. Anim. Sci. 2014, 44, 18-25. [CrossRef]

77. Sarica, S.; Corduk, M.; Suicmez, M.; Cedden, F.; Yildirim, M.; Kilinc, K. The effects of dietary L-carnitine supplementation on semen traits, reproductive parameters, and testicular histology of Japanese quail breeders. J. Appl. Poult. Res. 2007, 16, 178-186. [CrossRef]

78. Fattah, A.; Sharafi, M.; Masoudi, R.; Shahverdi, A.; Esmaeili, V. L-carnitine is a survival factor for chilled storage of rooster semen for a long time. Cryobiology 2017, 74, 13-18. [CrossRef] [PubMed]

79. Fattah, A.; Sharafi, M.; Masoudi, R.; Shahverdi, A.; Esmaeili, V.; Najafi, A. L-Carnitine in rooster semen cryopreservation: Flow cytometric, biochemical and motion findings for frozen-thawed sperm. Cryobiology 2017, 74, 148-153. [CrossRef]

80. Oso, A.O.; Lala, O.A.; Oke, E.O.; Williams, G.A.; Taiwo, A.G.; Ogunsola, Z.O. Effects of dietary supplementation with vitamin E, selenium yeast or both on egg incubation response, embryonic development, keet quality, and posthatch growth of helmeted guinea fowl breeders. Trop. Anim. Health Prod. 2020, 52, 2667-2675. [CrossRef]

81. Attia, Y.A.; Qota, E.M.; Bovera, F.; Tag El-Din, A.E.; Mansour, S.A. Effect of amount and source of manganese and/or phytase supplementation on productive and reproductive performance and some physiological traits of dual purpose cross-bred hens in the tropics. Br. Poult. Sci. 2010, 51, 235-245. [CrossRef]

82. Di Fiore, M.M.; Lamanna, C.; Assisi, L.; Botte, V. Opposing effects of D-aspartic acid and nitric oxide on tuning of testosterone production in mallard testis during the reproductive cycle. Reprod. Biol. Endocrinol. 2008, 6, 28. [CrossRef]

83. Giacone, F.; Condorelli, R.A.; Mongiò̀, L.M.; Bullara, V.; La Vignera, S.; Calogero, A.E. In vitro effects of zinc, D-aspartic acid, and coenzyme-Q10 on sperm function. Endocrine 2017, 56, 408-415. [CrossRef] [PubMed] 
84. Murakami, A.E.; Rodrigueiro, R.J.B.; Santos, T.C.; Ospina-Rojas, I.C.; Rademacher, M. Effects of dietary supplementation of meat-type quail breeders with guanidinoacetic acid on their reproductive parameters and progeny performance. Poult. Sci. 2014, 93, 2237-2244. [CrossRef] [PubMed]

85. Nasirikhah, A.; Zhandi, M.; Shakeri, M.; Sadeghi, M.; Ansari, M.; Deldar, H.; Yousefi, A.R. Dietary Guanidinoacetic acid modulates testicular histology and expression of c-Kit and STRA8 genes in roosters. Theriogenology 2019, 130, 140-145. [CrossRef] [PubMed]

86. Zhang, G.F.; Yang, Z.B.; Wang, Y.; Yang, W.R.; Jiang, S.Z.; Gai, G.S. Effects of ginger root (Zingiber officinale) processed to different particle sizes on growth performance, antioxidant status, and serum metabolites of broiler chickens. Poult. Sci. 2009, 88, $2159-2166$. [CrossRef]

87. Zhao, X.; Yang, Z.B.; Yang, W.R.; Wang, Y.; Jiang, S.Z.; Zhang, G.G. Effects of ginger root (Zingiber officinale) on laying performance and antioxidant status of laying hens and on dietary oxidation stability. Poult. Sci. 2011, 90, 1720-1727. [CrossRef] [PubMed]

88. Altawash, A.S.A.; Shahneh, A.Z.; Moravej, H.; Ansari, M. Chrysin-induced sperm parameters and fatty acid profile changes improve reproductive performance of roosters. Theriogenology 2017, 104, 72-79. [CrossRef]

89. Zhandi, M.; Ansari, M.; Roknabadi, P.; Zare Shahneh, A.; Sharafi, M. Orally administered Chrysin improves post-thawed sperm quality and fertility of rooster. Reprod. Domest. Anim. 2017, 52, 1004-1010. [CrossRef] [PubMed]

90. Knight, P.G. Roles of inhibins, activins, and follistatin in the female reproductive system. Front. Neuroendocrinol. 1996, 17, 476-509. [CrossRef] [PubMed]

91. Bristol, S.K.; Woodruff, T.K. Follicle-restricted compartmentalization of transforming growth factor beta superfamily ligands in the feline ovary. Biol. Reprod. 2004, 70, 846-859. [CrossRef] [PubMed]

92. Ying, S.Y. Inhibins and activins: Chemical properties and biological activity. Proc. Soc. Exp. Biol. Med. 1987, 186, 253-264. [CrossRef]

93. Meachem, S.J.; Nieschlag, E.; Simoni, M. Inhibin B in male reproduction: Pathophysiology and clinical relevance. Eur. J. Endocrinol. 2001, 145, 561-571. [CrossRef]

94. Ying, S.Y. Inhibins, activins, and follistatins: Gonadal proteins modulating the secretion of follicle-stimulating hormone. Endocr Rev. 1988, 9, 267-293. [CrossRef] [PubMed]

95. Akhtar, M.F.; Wei, Q.; Zhu, H.; Chen, Z.; Ahmad, E.; Zhendan, S.; Shi, F. The role of active immunization against inhibin $\alpha$-subunit on testicular development, testosterone concentration and relevant genes expressions in testis, hypothalamus and pituitary glands in Yangzhou goose ganders. Theriogenology 2019, 128, 122-132. [CrossRef]

96. Moreau, J.D.; Satterlee, D.G.; Rejman, J.J.; Cadd, G.G.; Kousoulas, K.G.; Fioretti, W.C. Active immunization of Japanese quail hens with a recombinant chicken inhibin fusion protein enhances production performance. Poult. Sci. 1998, 77, 894-901. [CrossRef] [PubMed]

97. Lovell, T.M.; Knight, P.G.; Groome, N.P.; Gladwell, R.T. Changes in plasma inhibin A levels during sexual maturation in the female chicken and the effects of active immunization against inhibin alpha-subunit on reproductive hormone profiles and ovarian function. Biol. Reprod. 2001, 64, 188-196. [CrossRef]

98. Lovell, T.M.; Knight, P.G.; Groome, N.P.; Gladwell, R.T. Measurement of dimeric inhibins and effects of active immunization against inhibin alpha-subunit on plasma hormones and testis morphology in the developing cockerel. Biol. Reprod. 2000, 63, 213-221. [CrossRef] [PubMed]

99. Ahn, J.; You, S.; Kim, H.; Chaiseha, Y.; El Halawani, M. Effects of active immunization with inhibin alpha subunit on reproductive characteristics of turkey hens. Biol. Reprod. 2001, 65, 1594-1600. [CrossRef]

100. Voge, J.L.; Parker, J.B.; Wheaton, J.E. Effects of immunization against alpha-inhibin using two adjuvants on daily sperm production and hormone concentrations in ram lambs. Domest. Anim. Endocrinol. 2009, 37, 206-213. [CrossRef]

101. Hopkins, M.; Blundell, J.E. Energy balance, body composition, sedentariness and appetite regulation: Pathways to obesity. Clin. Sci. 2016, 130, 1615-1628. [CrossRef]

102. Landry, D.; Cloutier, F.; Martin, L.J. Implications of leptin in neuroendocrine regulation of male reproduction. Reprod. Biol. 2013, 13, 1-14. [CrossRef]

103. Childs, G.V.; Odle, A.K.; MacNicol, M.C.; MacNicol, A.M. The importance of leptin to reproduction. Endocrinology 2021, 162, bqaa204. [CrossRef]

104. Guzmán, A.; Hernández-Coronado, C.G.; Rosales-Torres, A.M.; Hernández-Medrano, J.H. Leptin regulates neuropeptides associated with food intake and GnRH secretion. Ann. Endocrinol. 2019, 80, 38-46. [CrossRef] [PubMed]

105. Zhang, J.; Gong, M. Review of the role of leptin in the regulation of male reproductive function. Andrologia 2018, 50, e12965. [CrossRef]

106. Lei, M.M.; Dai, Z.C.; Zhu, H.X.; Chen, R.; Chen, Z.; Shao, C.R.; Shi, Z.D. Impairment of testes development in Yangzhou ganders by augmentation of leptin receptor signaling. Theriogenology 2021, 171, 94-103. [CrossRef]

107. Lei, M.M.; Wu, S.Q.; Li, X.W.; Wang, C.L.; Chen, Z.; Shi, Z.D. Leptin receptor signaling inhibits ovarian follicle development and egg laying in chicken hens. Reprod. Biol. Endocrinol. 2014, 12, 25. [CrossRef]

108. Lei, M.M.; Wu, S.Q.; Shao, X.B.; Li, X.W.; Chen, Z.; Ying, S.J.; Shi, Z.D. Creating leptin-like biofunctions by active immunization against chicken leptin receptor in growing chickens. Domest. Anim. Endocrinol. 2015, 50, 55-64. [CrossRef]

109. Martins, A.D.; Moreira, A.C.; Sá, R.; Monteiro, M.P.; Sousa, M.; Carvalho, R.A.; Silva, B.M.; Oliveira, P.F.; Alves, M.G. Leptin modulates human Sertoli cells acetate production and glycolytic profile: A novel mechanism of obesity-induced male infertility? Biochim. Biophys. Acta 2015, 1852, 1824-1832. [CrossRef] [PubMed] 
110. Amjad, S.; Baig, M.; Zahid, N.; Tariq, S.; Rehman, R. Association between leptin, obesity, hormonal interplay and male infertility. Andrologia 2019, 51, e13147. [CrossRef]

111. Malik, I.A.; Durairajanayagam, D.; Singh, H.J. Leptin and its actions on reproduction in males. Asian J. Androl. 2019, 21, $296-299$. [CrossRef]

112. Haron, M.N.; D'Souza, U.J.; Jaafar, H.; Zakaria, R.; Singh, H.J. Exogenous leptin administration decreases sperm count and increases the fraction of abnormal sperm in adult rats. Fertil. Steril. 2010, 93, 322-324. [CrossRef] [PubMed]

113. Wang, X.; Zhang, X.; Hu, L.; Li, H. Exogenous leptin affects sperm parameters and impairs blood testis barrier integrity in adult male mice. Reprod. Biol. Endocrinol. 2018, 16, 55. [CrossRef]

114. Bakst, M.R.; Dymond, J.S. Artificial insemination in poultry. In Success in Artificial Insemination-Quality of Semen and Diagnostics Employed; Lemma, A., Ed.; IntechOpen: London, UK, 2013; pp. 722-723. [CrossRef]

115. Hudson, G.H.; Omprakash, A.V.; Premavalli, K.; Dhinakar Raj, G. Quantifying sperm egg interaction to assess the breeding efficiency through artificial insemination in guinea fowls. Br. Poult. Sci. 2017, 58, 192-199. [CrossRef] [PubMed]

116. Van Krey, H.P.; Siegel, P.B. A revised artificial insemination schedule for broiler breeder hens. Poult. Sci. 1976, 55, 725-728. [CrossRef] [PubMed]

117. Thélie, A.; Grasseau, I.; Grimaud-Jottreau, I.; Seigneurin, F.; Blesbois, E. Semen biotechnology optimization for successful fertilization in Japanese quail (Coturnix japonica). Theriogenology 2019, 139, 98-105. [CrossRef] [PubMed]

118. Lierz, M.; Reinschmidt, M.; Müller, H.; Wink, M.; Neumann, D. A novel method for semen collection and artificial insemination in large parrots (Psittaciformes). Sci. Rep. 2013, 3, 2066. [CrossRef] [PubMed]

119. Bonato, M.; Malecki, I.A.; Brand, Z.; Cloete, S.W.P. Developing a female-only flock for artificial insemination purposes in ostriches: Progress and future directions. Anim. Reprod. Sci. 2017, 180, 85-91. [CrossRef]

120. Weigend, S.; Romanov, M.N.; Rath, D. Methodologies to Identify, Evaluate and Conserve Poultry Genetic Resources. In Proceedings of the XXII World's Poultry Congress \& Exhibition: Participant List \& Full Text CD + Book of Abstracts, Istanbul, Turkey, 8-13 June 2004; WPSA-Turkish Branch: Istanbul, Turkey, 2004; p. 84.

121. Blesbois, E. Freezing avian semen. Avian Biol. Res. 2011, 4, 52-58. [CrossRef]

122. Hammerstedt, R.H.; Graham, J.K. Cryopreservation of poultry sperm: The enigma of glycerol. Cryobiology 1992, $29,26-38$. [CrossRef]

123. Fujihara, N. Simple and rapid cryopreservation of rooster spermatozoa. J. Low Temp. Med. 1991, 17, $128-131$.

124. Sakhatskij, N.I.; Tereshchenko, A.V.; Artemenko, A.B.; Tagirov, M.T. Influence of Nine-year Storage in Liquid Nitrogen on Reproductive Properties of Freeze-thawed Chicken Semen. In Proceedings of the 7th Baltic Poultry Conference, Riga, Latvia, 9 September 1999; Ministry of Agriculture: Riga, Latvia, 1999; pp. 86-88.

125. Pawluczuk, B.; Grunder, A.A. Research note: Comparison of three methods of collecting semen from ganders. Poult. Sci. 1989, 68, 1714-1717. [CrossRef]

126. Blanco, J.M.; Gee, G.; Wildt, D.E.; Donoghue, A.M. Species variation in osmotic, cryoprotectant, and cooling rate tolerance in poultry, eagle, and peregrine falcon spermatozoa. Biol. Reprod. 2000, 63, 1164-1171. [CrossRef]

127. Łukaszewicz, E.; Chrzanowska, M.; Jerysz, A.; Chełmońska, B. Attempts on freezing the Greylag (Anser anser L.) gander semen. Anim. Reprod. Sci. 2004, 80, 163-173. [CrossRef]

128. Bychko, S.V.; Artemenko, O.B.; Tereshchenko, O.V.; Linnik, T.P. Gander sperm cryopreservation in plastic straws. Probl. Cryobiol. Cryomedicine 2004, 4, 61-66.

129. Tai, J.-J.L.; Chen, J.C.; Wu, K.C.; Wang, S.D.; Tai, C. Cryopreservation of gander semen. Br. Poult. Sci. 2001, 42, 384-388. [CrossRef]

130. Lake, P. Artificial insemination in poultry and the storage of semen-A re-appraisal. World's Poult. Sci. J. 1967, $23,111-132$. [CrossRef] [PubMed]

131. Gumułka, M.; Rozenboim, I. Mating activity and sperm penetration assay in prediction of the reproduction potential of domestic goose ganders in a harem system. Anim. Reprod. Sci. 2015, 161, 138-145. [CrossRef]

132. Gumułka, M.; Rozenboim, I. Effect of the age of ganders on reproductive behavior and fertility in a competitive mating structure. Ann. Anim. Sci. 2017, 17, 733-746. [CrossRef]

133. Łukaszewicz, E.; Jerysz, A.; Kowalczyk, A. Reproductive season and male effect on quantitative and qualitative traits of individually collected Muscovy duck (Cairina moschata) semen. Reprod. Domest. Anim. 2020, 55, 1735-1746. [CrossRef]

134. Mishina, Y.; Whitworth, D.J.; Racine, C.; Behringer, R.R. High specificity of Müllerian-inhibiting substance signaling in vivo. Endocrinology 1999, 140, 2084-2088. [CrossRef]

135. Rey, R.; Lukas-Croisier, C.; Lasala, C.; Bedecarrás, P. AMH/MIS: What we know already about the gene, the protein and its regulation. Mol. Cell. Endocrinol. 2003, 211, 21-31. [CrossRef]

136. Fujisawa, M.; Yamasaki, T.; Okada, H.; Kamidono, S. The significance of anti-Müllerian hormone concentration in seminal plasma for spermatogenesis. Hum. Reprod. 2002, 17, 968-970. [CrossRef]

137. Cai, K.; Hua, G.; Ahmad, S.; Liang, A.; Han, L.; Wu, C.; Yang, F.; Yang, L. Action mechanism of inhibin $\alpha$-subunit on the development of Sertoli cells and first wave of spermatogenesis in mice. PLoS ONE 2011, 6, e25585. [CrossRef]

138. Tran, D.; Picard, J.; Campargue, J.; Josso, N. Immunocytochemical detection of anti-Müllerian hormone in Sertoli cells of various mammalian species including human. J. Histochem. Cytochem. 1987, 35, 733-743. [CrossRef]

139. Jost, A.; Vigier, B.; Prépin, J.; Perchellet, J.P. Studies on sex differentiation in mammals. Recent Prog. Horm. Res. 1973, $29,1-41$. [CrossRef] [PubMed] 
140. Weenen, C.; Laven, J.S.E.; Von Bergh, A.R.M.; Cranfield, M.; Groome, N.P.; Visser, J.A.; Kramer, P.; Fauser, B.C.J.M.; Themmen, A.P.N. Anti-Müllerian hormone expression pattern in the human ovary: Potential implications for initial and cyclic follicle recruitment. Mol. Hum. Reprod. 2004, 10, 77-83. [CrossRef]

141. Johnson, P.A.; Kent, T.R.; Urick, M.E.; Giles, J.R. Expression and regulation of anti-mullerian hormone in an oviparous species, the hen. Biol. Reprod. 2008, 78, 13-19. [CrossRef]

142. Johnson, P.A.; Kent, T.R.; Urick, M.E.; Trevino, L.S.; Giles, J.R. Expression of anti-Mullerian hormone in hens selected for different ovulation rates. Reproduction 2009, 137, 857-863. [CrossRef]

143. Wojtusik, J.; Johnson, P.A. Vitamin D regulates anti-Mullerian hormone expression in granulosa cells of the hen. Biol. Reprod. 2012, 86, 91. [CrossRef]

144. Chen, R.; Dai, Z.C.; Zhu, H.X.; Lei, M.M.; Li, Y.; Shi, Z.D. Active immunization against AMH reveals its inhibitory role in the development of pre-ovulatory follicles in Zhedong White geese. Theriogenology 2020, 144, 185-193. [CrossRef] 